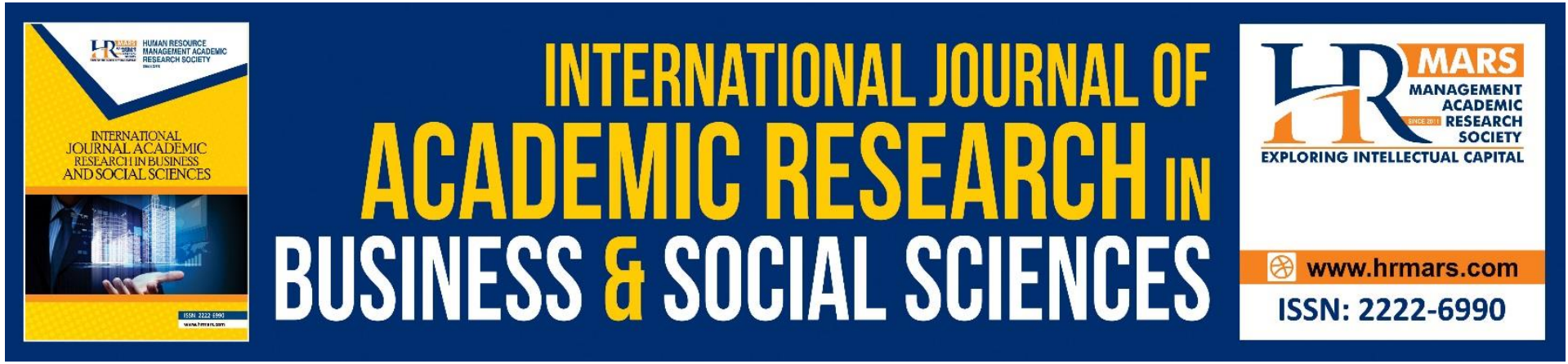

\title{
Residents' Perception on the Impact of Urban Development on Water Quality in Kabul City, Afghanistan
}

Safiullah Zahid, M. Zainora Asmawi and Muhammad Faris Abdullah

To Link this Article: http://dx.doi.org/10.6007/IJARBSS/v11-i6/10212

DOI:10.6007/IJARBSS/v11-i6/10212

Received: 10 April 2021, Revised: 12 May 2021, Accepted: 29 May 2021

Published Online: 14 June 2021

In-Text Citation: (Zahid et al., 2021)

To Cite this Article: Zahid, S., Asmawi, M. Z., \& Abdullah, M. F. (2021). Residents' Perception on the Impact of Urban Development on Water Quality in Kabul City, Afghanistan. International Journal of Academic Research in Business and Social Sciences, 11(6), 818-827.

Copyright: @ 2021 The Author(s)

Published by Human Resource Management Academic Research Society (www.hrmars.com)

This article is published under the Creative Commons Attribution (CC BY 4.0) license. Anyone may reproduce, distribute, translate and create derivative works of this article (for both commercial and non-commercial purposes), subject to full attribution to the original publication and authors. The full terms of this license may be seen at: http://creativecommons.org/licences/by/4.0/legalcode

Vol. 11, No. 6, 2021, Pg. 818- 827

Full Terms \& Conditions of access and use can be found at http://hrmars.com/index.php/pages/detail/publication-ethics 


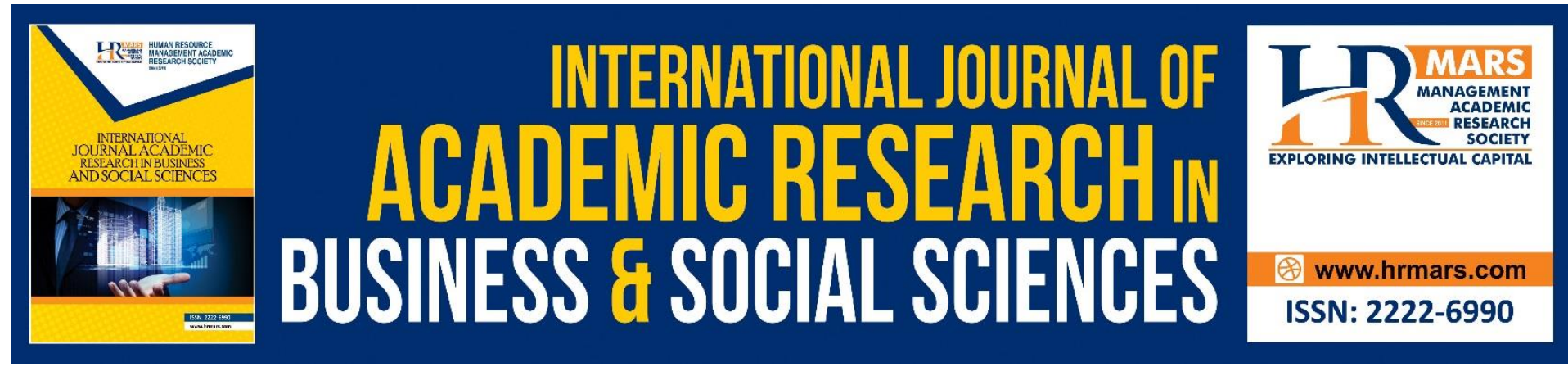

\title{
Residents' Perception on the Impact of Urban Development on Water Quality in Kabul City, Afghanistan
}

\section{Safiullah Zahid, M. Zainora Asmawi and Muhammad Faris Abdullah}

Department of Urban \& Regional Planning, Kulliyyah of Architecture \& Environmental Design (KAED), International Islamic University of Malaysia (IIUM), 53100, Selangor, Malaysia.

Email: zainora@iium.edu.my

\begin{abstract}
Kabul, as one of the biggest cities and capital of Afghanistan, has been severely affected by the past few decades of war in the country. The Kabul city population has significantly increased after 2001, which resulted in the fastest urban development of the city. About $70 \%$ of the Kabul city residents living in the informal settlement, nearly two-thirds of its population do not have access to the city water supply network, and the Kabul city drinking water is mainly being supplied through shallow wells. Proper sanitation system also does not exist in the city. This resulted in the decline of water quality. Indeed, groundwater analyses display a continued reduction in water quality due to increases in pollution. Thus, the main purpose of this research is to analyse the effects of urban development on water quality of groundwater through resident's perception. Therefore, a survey questionnaire was circulated among 429 persons, which shows that about half of the respondents were not satisfied with their home drinking water quality. Besides, the analyses of data also revealed that rapid urbanisation has a significant impact on water quality and that the rapid population growth, stormwater, water pollution, colour of water, septic tank, drainage, and pit latrine are the main elements that contribute to the impact of urban development on water quality of the city.

Keywords: Urban Development, Population Growth, Water Quality, Residents Perception, Groundwater
\end{abstract}

\section{Introduction}

Afghanistan has an old history of urban settlement, which dates back to $3000 \mathrm{BC}$ and counting as one of the oldest centres of civilisation in central Asia (Habib \& Kidokoro, 2015). However, bypassing nearly two decades of wars Afghanistan become one of the poorest countries in the world, more than five million people emigrated to the neighbouring countries, until the new government came into existence in 2001 (Beall \& Schütte, 2006). Hence, the major cities of the country show rapid population growth due to the returning of emigrant and internal displacement (Majidi, 2011). Even though Kabul as one of the biggest city and capital of Afghanistan has significantly affected, the Kabul city population has rapidly increased from 
1.5million in 2001 to about 4.9 million people in 2015 which resulted the Kabul city become the fifth rapidly growing city in the world due to fastest urbanisation and population growth, where about $70 \%$ of the people are currently living in an informal settlement in Kabul city (Ahmadi \& Kajita, 2017). Besides, the residents of the city are suffering from different types of environmental challenges such as air pollution, weak solid waste management, absence of water sanitation, safe drinking water and green areas (Afghanistan's Environment, 2008).

It was discovered that nearly $27.5 \%$ of the Kabul city residents have access to the water supply network (Zaryab et al., 2017). The Kabul city drinking water is mainly being supplied by privately or community-owned shallow wells of groundwater, with a depth of normally less than 30m (Mack, Chornack, \& Taher, 2013). The groundwater level decreased by $1.7 \mathrm{~m} /$ year during the years 2008 - 2016 due to rapid increase in the population growth and using the shallow well as the main source of drinking water (Zaryab et al., 2017). Besides, a research carried out in $\mathbf{2 0 0 9}$ for the development of Kabul city master plan displayed, a required water demand of 123.4 million $\mathrm{m}^{3} /$ year for the Kabul city. However, the Kabul city groundwater storage was estimated nearly 44 million $\mathrm{m}^{3} /$ year, so if daily consumption of 50 lit/day per capita were to be considered, then it would only supply water for 2 million people (JICA, 2009). Therefore, to solve the water decline issue in Kabul, the government started the aquifer recharge project in early 2017. This project aims to store the water discharging from snow melting or rainfall to further recharge the local aquifer layer ("Kabul Managed Aquifer Recharge Project Preparation," 2017). The feasibility study for the construction of Shahtoot dam located in the southwest of Kabul city on the Kabul river was completed in 2010, and the estimated capacity of the water supply after completion for this dam is an average of 87.2 million $\mathrm{m}^{3} /$ year (Zaryab et al., 2017). Collectively, the dam and groundwater can solve the water supply issues of Kabul city. In spite of this, in 2018, the Ministry of Energy and Water had announced that the government will soon start the implementation of the Shahtoot dam after they resolve the land acquisition issue and environmental impact study by the Ministry of Urban Development and Land (Omid, 2018). Hence, until the construction of this dam, the groundwater can be counted as the main source of drinking water.

Additionally, the appropriate system for wastewater treatment does not exist in Kabul city and the groundwater pollution associated infection also increased in the citizen, which shows the negative path of the groundwater due to increases of the pollution (Zaryab et al., 2017). Excluding the Microryan area, which is the only area in Kabul city that has the sewerage system and treatment plant (JICA, 2011). Further, the absence of public sewerage system resulted that some of the people make septic tank; while others build a simple latrine and that caused to mix the sewerage with underground water and increasing the groundwater pollution (Constable, 2017). Therefore, the main reasons for decreasing the level of water quality noticed; quick population growth, which became tripled in a few decades, fastest urbanisation and industrial development, and economic growth (Akhtar, 2017).

Furthermore, previous studies show the GIS-based assessment of the Kabul city water quality shows, that the water quality in Kabul City is not suitable for drinking purpose due to increased level of lead, arsenic, with coli and E-coli, while the level of alkalinity and bicarbonate are also higher close to the city (Shah, 2011). Besides, the chemical analysis of the water quality in Kabul city revealed that the water quality in Kabul city is much more polluted and has a serious risk due to the high level of magnesium, boron, manganese, and sodium (Sundem, 2014). Additionally, the analysed of about 227 water well samples for toxic elements of the water quality in Kabul city resulted that, three toxic elements among all ten tested have exceeded from the World Health Organization (WHO) guideline which is: 
chromium in $0.9 \%$, uranium in $19.4 \%$ and arsenic in $7 \%$ of the samples, that represent the groundwater pollution of the Kabul city (Kato et al., 2016). Moreover, the analysed of nearly 450 samples for biological characteristics of water from water supply network of Kabul city resulted in the existence of Fecal Coliform bacteria by $9.6 \%$ and Total Coliform bacteria by $12.9 \%$ on the total water sample tested, which also shows the groundwater pollution of the city (Zahid, Asmawi \& Abdullah, 2019).

Thus, the main purpose of this study is to identify the resident's perception about water quality and to analyse the impact of urban development on groundwater quality in the Kabul city. However, many authors have analysed the groundwater quality of Kabul city. While, the significance of this study is that it covers the resident's perceptions about water quality and the impact of urban development on it. Though, to achieve the objectives of this study, a survey questionnaire has been developed and circulated among the residents of the city.

\section{Methods}

The study area of Kabul city, the capital of Afghanistan is located in the north-eastern part of the country. The city is surrounded by mountains and situated at 1,800 meter above sea level. Besides, Kabul city consists of 22 municipality districts (JICA, 2011). The research method used for this study consisted of both qualitative and quantitative methods. The trend of Kabul urban development has been analysed using the qualitative research method. Hence, the resident's perception about water quality and the impact of urban development have been analysed using the quantitative method of the research. The questionnaire survey has been circulated among the residents of Kabul city through the internet using the google form and as a hard copy between the city dwellers to know about their perception in regards to the water quality and the impact of the urban development on the groundwater quality. As a result, 429 persons have filled the survey questionnaire form and responded to all the questions stipulated in the questionnaire. The survey questionnaire was consisting of three parts, first demographic information of the respondent, second the questions related to the water quality, and the third part of the survey questionnaire was about the urban development impact on the water quality.

\section{Data Analysis and Discussion}

The analysis of demographic data achieved through the questionnaire survey shows that nearly $60 \%$ of the total respondents were male and the remaining about $40 \%$ female. It also illustrates the age variation of the respondents, which is within the range of 18 years old to above 55 years. The educational level of the respondents was also varied; most of them $(53.1 \%)$ had completed a bachelor's degree. Besides, most of the respondents $(35.4 \%)$ have a monthly income of ranged between $\$ 201$ and \$500 (Table -1). 
Table 1 Demographic Information

\begin{tabular}{|c|l|c|c|}
\hline Information & \multicolumn{1}{|c|}{ Group } & Percentage & $\begin{array}{c}\text { Number of } \\
\text { Respondents }\end{array}$ \\
\hline \multirow{4}{*}{ Gender } & Male & 59.7 & 256 \\
\cline { 2 - 4 } & Female & 40.3 & 173 \\
\hline \multirow{5}{*}{ Age } & $18-24$ & 67.1 & 288 \\
\cline { 2 - 4 } & $25-34$ & 24.7 & 106 \\
\cline { 2 - 4 } & $35-44$ & 5.8 & 25 \\
\cline { 2 - 4 } & $45-54$ & 1.6 & 7 \\
\cline { 2 - 4 } & Above 55 & 0.7 & 3 \\
\hline \multirow{5}{*}{ Education } & Lower than High School & 1.4 & 6 \\
\cline { 2 - 4 } & Graduate from High School & 29.1 & 125 \\
\cline { 2 - 4 } & Graduate from Technical Institute & 3.5 & 15 \\
\cline { 2 - 4 } & Bachelor's Degree & 53.1 & 228 \\
\cline { 2 - 4 } & Post Graduate Degree & 12.8 & 55 \\
\hline \multirow{5}{*}{ Income } & Less than \$200 & 25.9 & 111 \\
\cline { 2 - 4 } & $\$ 201-\$ 500$ & 35.4 & 152 \\
\cline { 2 - 4 } & $\$ 501-\$ 1000$ & 19.3 & 83 \\
\cline { 2 - 4 } & $\$ 1001-\$ 1500$ & 8.2 & 35 \\
\cline { 2 - 4 } & $\$ 1501$ and Above & 11.2 & 48 \\
\hline
\end{tabular}

However, the analysis of data illustrated in Figure 1 below shows that the majority of the respondents (53.6\%) were using the well as the main source of drinking water, following by $41.7 \%$ have access to the water supply network. While the main source for water supply network is also the groundwater. Additionally, the data stipulated in Table- 2 below describes that the mean value for most of the items related to water quality was more than the moderate level and nearly reached to the scaled level of good except the value for safe to drink, which is close to the medium level. Besides, Figure 2 below demonstrates that more than half of the respondents agreed about their home drinking water contamination.

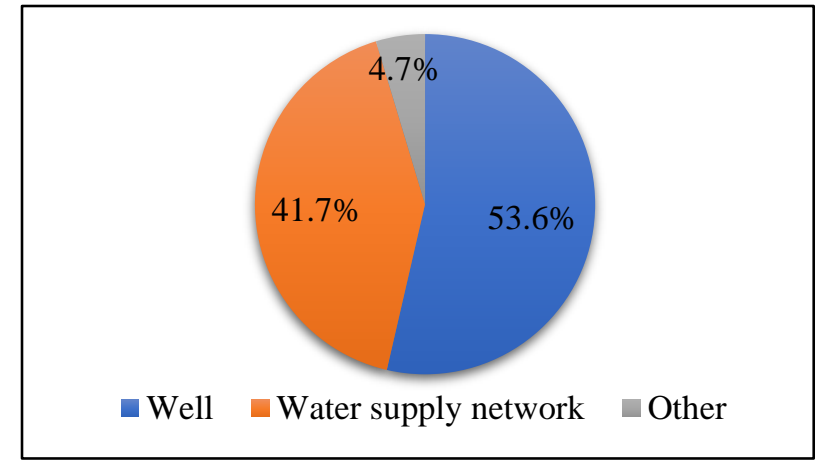

Figure 1: Sources of Drinking Water

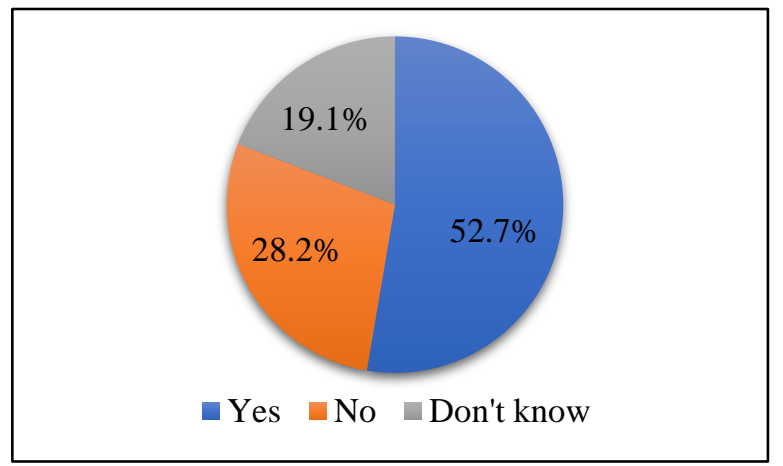

Figure 2: Residents Perception about their Home 
Table 2: Residents Perception on Drinking Water Quality

\begin{tabular}{|l|c|c|c|c|c|}
\hline \multicolumn{7}{|c|}{ Descriptive Statistics } \\
\hline & N & Min & Max & Mean & SD \\
\hline Colour & 429 & 1 & 5 & 3.76 & 0.974 \\
\hline Taste & 429 & 1 & 5 & 3.45 & 1.198 \\
\hline Odour & 429 & 1 & 5 & 3.68 & 1.039 \\
\hline Clearness & 429 & 1 & 5 & 3.60 & 1.095 \\
\hline $\begin{array}{l}\text { Safe to } \\
\text { drink }\end{array}$ & 429 & 1 & 5 & 3.09 & 1.245 \\
\hline $\begin{array}{l}\text { Valid N } \\
\text { (listwise) }\end{array}$ & 429 & & & & \\
\hline $\begin{array}{l}\text { Standard Deviation (SD), 1=Very Poor, } \\
\text { 5=Very Good }\end{array}$ \\
\hline
\end{tabular}

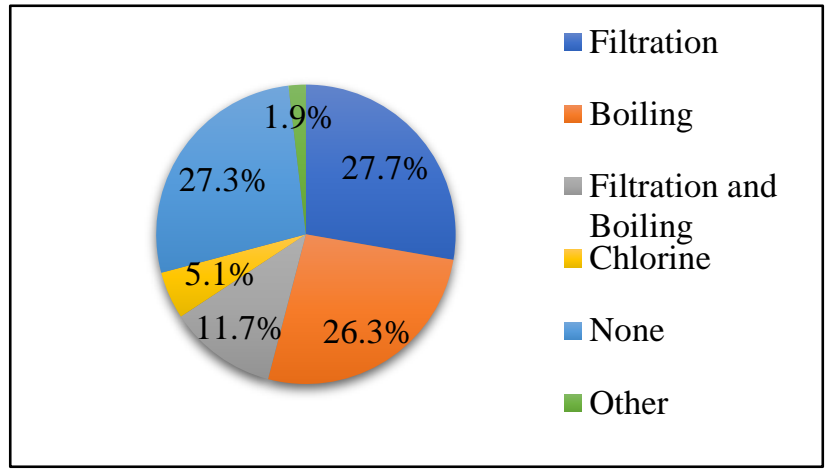

Figure 3: Water Quality Improvement Method

The high amount of dissatisfaction among the residents about the groundwater quality is due to contamination of groundwater with a different type of pollutants. As stated above, many authors have also analysed the groundwater quality of the Kabul city and revealed that the Kabul city groundwater had been polluted with different types of chemical and biological elements. Besides, Figure 3 above shows that $27.7 \%$ of the respondents are using the filtration system in their houses to improve their drinking water quality; where about $26.3 \%$ are boiling the water. Moreover, nearly $11.7 \%$ are using both filtration system and boiling. While the chlorine is used by $5.1 \%$ of the respondents and $27.3 \%$ are drinking tap water without using any improvement method. However, about $1.9 \%$ of the respondents indicated other types, such as buying bottled water. Additionally, the respondents were also asked to provide their opinion about some of the urban development factors' impact on water quality (Table 3).

Table 3: Residents' perception about the negative impact of urban development factors on the water quality

\begin{tabular}{|l|c|c|c|c|c|}
\hline \multicolumn{5}{|c|}{ Descriptive Statistics } \\
\hline & $\mathrm{N}$ & Min & Max & $\begin{array}{c}\text { Mea } \\
\mathrm{n}\end{array}$ & $\begin{array}{c}\text { Std. } \\
\text { Deviation }\end{array}$ \\
\hline Rapid Population growth & 429 & 1 & 5 & 4.29 & 1.049 \\
\hline Rapid Urbanization growth & 429 & 1 & 5 & 4.00 & 1.150 \\
\hline Stormwater & 429 & 1 & 5 & 3.14 & 1.403 \\
\hline Urban Wastewater & 429 & 1 & 5 & 4.35 & 1.061 \\
\hline Septic tank & 429 & 1 & 5 & 4.17 & 1.110 \\
\hline Pit Latrine & 429 & 1 & 5 & 4.26 & 1.030 \\
\hline Industrial Pollution & 429 & 1 & 5 & 4.03 & 1.169 \\
\hline Solid waste dump irregularly & 429 & 1 & 5 & 4.15 & 1.064 \\
\hline Limited access to water supply & 429 & 1 & 5 & 4.11 & 1.131 \\
\hline Inadequate transportation & 429 & 1 & 5 & 3.62 & 1.256 \\
\hline Valid N (listwise) & 429 & & & & \\
\hline
\end{tabular}

$1=$ No impact, $5=$ High impact

Table 3 above shows that rapid urbanisation growth has a significance impact on water quality. Furthermore, the regression analysis has been conducted among different variables stipulated in the survey questionnaire, such as physical characteristics of water quality, water 
pollution, sources of pollution, population growth, and urban development. Therefore, the result for the best fit model achieved is described in Table 4 below.

Table 4: Regression Model for the Impact of Urban Development on the Water Quality

\begin{tabular}{|c|c|c|c|c|}
\hline \multicolumn{5}{|c|}{ Model Summary } \\
\hline Model & $\mathrm{R}$ & $\begin{array}{c}\mathrm{R} \\
\text { Square }\end{array}$ & $\begin{array}{c}\text { Adjusted R } \\
\text { Square }\end{array}$ & $\begin{array}{c}\text { Std. Error of } \\
\text { the } \\
\text { Estimate }\end{array}$ \\
\hline 1 & $.543^{\mathrm{a}}$ & .294 & .283 & .974 \\
\hline $\begin{array}{l}\text { a. Predictors: (Constant), Pit Latrine, Colour, Stormwater, } \\
\text { Septic Tank, Water Pollution, Rapid population growth, } \\
\text { Drainage }\end{array}$ \\
\hline
\end{tabular}

Table 4 above shows the regression model for assessing the impact of urban development on the water quality, the $\mathrm{R}^{2}$ value for the above model is 0.294 which mean the rapid population growth, stormwater, water pollution, the colour of water, septic tank, drainage and pit latrine as independent variables have about $29.4 \%$ of the variance with the dependent variable of rapid urbanisation growth. The $\mathrm{R}^{2}$ value for this model is not much more, but the independent variables are highly significantly correlated with the dependent variables (see Table 5). Therefore, this model is the best fit model. 
Table 5: Regression Coefficients for the Impact of Urban Development on the Water Quality

\begin{tabular}{|c|c|c|c|c|c|}
\hline \multicolumn{6}{|c|}{ Coefficients $^{a}$} \\
\hline \multirow{2}{*}{ Model } & \multicolumn{2}{|c|}{$\begin{array}{l}\text { Unstandardise } \\
\text { d Coefficients }\end{array}$} & \multirow{2}{*}{$\begin{array}{c}\text { Standardis } \\
\text { ed } \\
\text { Coefficient } \\
\text { s } \\
\text { Beta }\end{array}$} & \multirow{2}{*}{$\mathrm{t}$} & \multirow{2}{*}{ Sig. } \\
\hline & B & $\begin{array}{l}\text { Std. } \\
\text { Error }\end{array}$ & & & \\
\hline (Constant) & 0.591 & $\begin{array}{c}0.32 \\
5 \\
\end{array}$ & & 1.816 & 0.070 \\
\hline $\begin{array}{l}\text { Rapid } \\
\text { population } \\
\text { growth }\end{array}$ & 0.437 & $\begin{array}{c}0.04 \\
9\end{array}$ & 0.399 & 8.958 & 0.000 \\
\hline Stormwater & 0.104 & $\begin{array}{c}0.03 \\
5\end{array}$ & 0.126 & 2.993 & 0.003 \\
\hline 1 Water $\begin{array}{l}\text { Pollution } \\
\end{array}$ & 0.103 & $\begin{array}{c}0.04 \\
5 \\
\end{array}$ & 0.102 & 2.302 & 0.022 \\
\hline Colour & 0.085 & $\begin{array}{c}0.04 \\
9\end{array}$ & 0.072 & 1.716 & 0.087 \\
\hline Septic Tank & 0.132 & $\begin{array}{c}0.05 \\
8\end{array}$ & 0.115 & 2.266 & 0.024 \\
\hline Drainage & -0.116 & $\begin{array}{c}0.05 \\
6\end{array}$ & -0.106 & -2.069 & 0.039 \\
\hline Pit Latrine & 0.106 & $\begin{array}{c}0.04 \\
9\end{array}$ & 0.095 & 2.137 & 0.033 \\
\hline
\end{tabular}

Table 5 above describes the coefficients for the impact of urban development on water quality. Thus, the regression equation based on these coefficients described above in Table- 5 is drawn as follow:

$$
\begin{aligned}
Y=0.591+ & 0.437 X 1+0.104 X 2+0.103 X 3+0.085 X 4+0.132 X 5-0.116 X 6 \\
& +0.106 X 7
\end{aligned}
$$

Where, $Y=$ Impact of rapid urban development on the water quality, $X 1=$ rapid population growth, $\mathrm{X} 2=$ stormwater, $\mathrm{X} 3=$ water pollution, $\mathrm{X} 4=$ colour of water, $\mathrm{X} 5=$ septic tank, $X 6=$ drainage, and $X 7=$ pit latrine. Consequently, the above equation shows that all the independents' variables have a significant positive relationship with the dependent variables except the drainage, which has a negative correlation. Besides, it has been concluded from the above regression analysis that the rapid urbanisation will impact the groundwater quality through producing different kinds of pollution, which can affect the water quality. In this relation, the rapid population growth is contributing the most important roles in the urban development impact on the water quality and drainage provide the less important. However, the water pollution, septic tank, pit latrine, colour of water, and stormwater were also influencing the impact of urbanisation on water quality. 


\section{Conclusion}

The review of the Kabul city urban development trend shows that Kabul city has faced rapid urbanisation growth after 2001, which is due to the fastest increase of the population and non-implementation of the city master plan, which resulted in nearly $70 \%$ of the residents living in the informal settlement. That caused to limit the residents' access to the most important urban services. The estimation shows that two-third of its population do not have access to the water supply network, and the proper sanitation and its treatment system also do not exist in Kabul city. However, the main purpose of this study was to investigate the impact of urban development on water quality and to analyse the residents' perception about water quality. Therefore, the result achieved through analysing the data of the survey questionnaire circulated among 429 persons shows that more than half of the respondents were not satisfied with their home drinking water. Additionally, it has been revealed that the rapid urban development has its significant impact on the water quality and the major elements that contribute to the impact of urban development on the water quality are the fastest population growth, stormwater, water pollution, colour of water, septic tank, drainage and pit latrine which resulted because of fastest increase in informal settlements.

\section{References}

Mallin, M. (2009). Effect of Human Land Development on Water Quality. In S. Ahuja (Ed.), Handbook of water purity and quality (pp. 67-94). Wilmington: Academic Press.

Afghanistan's environment 2008. (2008). United Nation Environment Programme. Retrieved from https://postconflict.unep.ch/publications/afg_soe_E.pdf

Shah, A. (2011). GIS based Ground Water Quality Analysis in Kabul City Region. Geospatial World Forum, 1-13. Retrieved from https://www.researchgate.net/publication /284352 960_GIS_based_Ground_Water_Quality_Analysis_in_Kabul_City_Region

Ahmadi, A. S., \& Kajita, Y. (2017). Evaluation of urban land development direcction in kabul city, Afghanistan. World Academy of Science, Engineering and Technology International Journal of Urban and Civil Engineering, 11(2), 152-162.

Akhtar, Z. K. (2017). Declining the Amount of Safe Drinking water in Afghanistan; An emerging pollution threat Pajhwok Afghan News. Retrieved April 21, 2018, from https://www.pajhwok.com/en/opinions/declining-amount-safe-drinking-waterafghanistan-emerging-pollution-threat

Beall, J., \& Schütte, S. (2006). Urban Livelihoods in Afghanistan. Afghanistan Research and Evaluation Unit, Synthesis Paper Series, 1-65. Retrieved from https:// core.ac.uk/download/pdf/93237.pdf

Constable, P. (2017). In Kabul, access to safe drinking water is a matter of money - The Washington Post. Retrieved April 21, 2018, from https://www.washingtonpost.com/ world/asia_pacific/in-kabul-access-to-safe-drinking-water-is-a-matter-ofmoney/2017/08/31/714ea228-8124-11e7-9e7a20fa8d7a0db6_story.html?noredirect=on\&utm_term $=$. b16365454dc7

High Council for Urban Development approves Kabul City Urban Design Framework. (2018). Retrieved November 18, 2018, from https://president.gov.af/en/news/high-council-forurban-development-approves-kabul-city-urban-design-framework/

JICA. (2009). The Study for the Development of the Master Plan for the Kabul Metropolitan Area. Retrieved from http://www.oanda.com

JICA. (2011). Draft Kabul City Master Plan Chapter 6. Kabul. Retrieved from http://open_ jicareport.jica.go.jp/pdf/12058566_04.pdf 
Kabul Managed Aquifer Recharge Project Preparation. (2017). Retrieved November 22, 2018, from https://kmarp.com/home/

Kato, M., Azimi, M. D., Fayaz, S. H., Shah, M. D., Hoque, M. Z., Hamajima, N., Yoshinaga, M. (2016). Uranium in well drinking water of Kabul, Afghanistan and its effective, low-cost depuration using Mg-Fe based hydrotalcite-like compounds. Chemosphere, 165, 27-32. https://doi.org/10.1016/J.CHEMOSPHERE.2016.08.124

Mack, T. J., Chornack, M. P., \& Taher, M. R. (2013). Groundwater-level trends and implications for sustainable water use in the Kabul Basin, Afghanistan. Environment Systems and Decisions, 33(3), 457-467. https://doi.org/10.1007/s10669-013-9455-4

Majidi, N. (2011). Urban Returnees and Internally Displaced Persons in Afghanistan.

Omid, H. (2018). India To Help Build Shahtoot Dam In Kabul | TOLOnews. Retrieved January 30, 2020, from https://tolonews.com/business/india-help-build-shahtoot-dam-kabul

Uyanık, G. K., \& Güler, N. (2013). A Study on Multiple Linear Regression Analysis. Procedia Social and Behavioral Sciences, 106, 234-240.

https://doi.org/10.1016/j.sbspro.2013.12.027

Zaryab, A., Noori, A. R., Wegerich, K., \& Kløve, B. (2017). Assessment of water quality and quantity trends in Kabul aquifers with an outline for future drinking water supplies. Central Asian Journal of Water Research, 3(2), 3-11. Retrieved from http://www.waterca.org/article/1925-assessment-of-water-quality-and-quantity-trends-in-kabulaquifers-with-an-outline-for-future-water-supplies.

Zahid, S., Asmawi, M. Z., \& Abdullah, M. F. (2019). Assessment of the Groundwater Quality and Pollution in Kabul City, Afghanistan. Advanced Journal of Technical and Vocational Education, 3(2), 20-26. https://doi.org/10.26666/rmp.ajtve.2019.2.4 